\title{
(Re)Labelling: Mimicry, Between Identification and Subjectivation
}

\author{
Thari Jungen
}

When in 2015 the purported 'summer of migration' occurred, the question of how to deal with the pressure of assimilation within the discourse of citizenship became ubiquitous. Citizenship is not only a legal and bureaucratic tool of exclusion, it is comprised of cultural and social interaction. Furthermore, the unspoken and informal knowledge carried within the practice of citizenship leads to modalities of exclusion and participation. In this sphere, legal means are to a large extent ineffective. That gap within the daily practice of citizenship is plastic, providing for the racist, sexist and homophobic practices of 'othering', as well as production of a space for resistance. Within the triangle of habitus, status and origin, the social and cultural capital also produces the homogenous desire for normalcy. Although resistance does not depend solely on differently empowered realms, the question of agency in the practice of 'othering' occurs. Inside the labelling concept of Erwing Goffman (1986) and the theory of subjectivation of Michel Foucault (1988), the practice of 'othering' betrays its ambivalent basis. ${ }^{1}$ Therefore the need of a tool, without high level of restraint, difficult approach or complicit methodology, may be answered in this essay, within exploring the practice of mimicry as a subversive tool of reflection.

T. Jungen $(\bowtie)$

Graduate Program Performing Citizenship, HafenCity University Hamburg, Hamburg, Germany

(C) The Author(s) 2019

P. Hildebrandt et al. (eds.), Performing Citizenship, Performance

Philosophy, https://doi.org/10.1007/978-3-319-97502-3_13 
By referring to the concept of the postcolonial theorist Homi Bhabha (2004a), I will try to explain the ambivalence of mimicry practices in the following, between a repetition of the predominant discourse and the production of a reflective space through overstated repetition. While doing so, the historical figure of the jester - shown here in persona of Marthurine gives an example of the ambivalence of the Janus-faced discourse of mimicry (cf. Lemaignan 2009). The carnivalesque fool, sanctioned around 1622 , acts as a figure moving freely between the spheres of sovereignty and citizenry (cf. Lemaignan 2009). In March 2016, around 400 years later, a collective of so-called refugees, organized the Carnival al Lajin Al-Lajiàat. This carnival shows a reformed traditional yet contemporary practice to react to labelling and stigmatization in precarious social situations. Referring to Michail Bakhtin, the notion of carnival includes a collective form of mimicry which he described as 'laughter from below', therefore I will question in the following if mimicry, as a practice of exaggerated humorous repetitions, gives one the chance to emancipate oneself from the unsaid and informal habits of labelling and stigmatizing.

\section{Marthurine, le fou: The Emancipation of a Female JESTER}

Mimic parodies - as a pervasive method to play with language, combined with gesture - are historically determined due to the historical figure of the jester. As the following will illustrate, Marthurine, le fou, a famous jester from renaissance times, gives an example of how to play with selfdefined rules (cf. Lemaignan 2009). She was a female jester at the court of King Louis XIII - regarded as père du peuple ('father of the people') - at the Louvre, Paris. Mathurine was one of few women to have the role of court jester - a position which was, above all, dominated by men. As mentioned in literature, she was a former head of an army canteen, sharptongued and smart. The alleged homosexual King Henry III was thrilled by her wisdom and humour, worshipping her burlesque costumes. Marthurine played a dual role in the French absolutist state; she embodied the figure of the court jester but was also writing a yellow press newspaper, brimming with secret information from the court. In this way, Marthurine's actions were Janus-faced, as simultaneous citizen and jester in the postGutenberg era. 
Since she was in a powerful but delicate position, being in close contact with the inhabitants of Paris as well as being a member of the court, Marthurine was in a unique situation with regard to the exchanging of information between her, the people and the monarch. Nowadays she is remembered for two accomplishments: for her self-made costumes (she created several male and female characters, wearing outfits that she designed herself, such as fictional soldier's uniforms) and the trading of hidden messages in her newspaper Les Caquets de l'Accouchée. Although the content of the paper was labelled as gossip, her yellow press supplied the inhabitants of Paris with internal confidential information. The paper was secretly printed at the king's court and was regularly distributed by Marthurine from the Pont Neuf, thereby gaining new information through her encounters.

\section{Mimicry as a Fool's Game}

Marthurine, or more widely the figure of the jester, at once embodies a counter-figure of the predominant discourse, through the undermining of hierarchies. As a character, she conveys a reiteration of the theoretical discourse through the use of parody and jokes, here described as the practice of mimicry by Homi Bhabha (cf. 2004a, p. 85). Since Bhabha is speaking in his theory from a postcolonial perspective, I would like to broaden his approach. It is salient to note that, in addition to the 'othering' strategies of racist discourse, sexist and even homophobic practices also colonize their subjects within the predominant discourse. Therefore, my notion of a postcolonial theory does not strictly refer to the idea of migration and colonized people as the labelled other in purely racial terms, but also within the context of sexism and homophobia.

Within the performance of mimicry lies, on one the hand, the desire to become or produce an equality that clearly will never be reached; on the other hand, the obscurity of this performance gains the potential to process, to incorporate and even to absorb the alleged primal image, to indicate it is reflecting the alleged profound reality. ${ }^{3}$ Here primal image and its imitation no longer exist, but a copy has absorbed the primal image. The imitation of the primal image becomes an accident of its imitation - an invisible accident, in consistent danger of being absorbed - and not conversely (cf. Didi-Huberman 2001, pp. 15-21). With the Freudian theory of the doppelgänger, the discussion about the strangely familiar, rather than just mysterious fear and uncanniness, became an interesting topic for 
psychoanalysis, philosophy and the discourse around race. When Sigmund Freud $(2003$, p. 267) stated, ' $[\mathrm{t}]$ he prefix $u n$ in this term is the marker of repression', he is describing those actions that remain uncanny, even if the subject seems to be performing ordinarily. When speaking of doppelgänger, within the repetition of a subject, the primal image stays invisible without separate existence, remaining bound to the whole. The similarity seems to be uncanny because of its random allocation of the signifier and the signified. The double takes the role of a crossover, a mash-up, indicated through the ambivalence of a ghostly afterimage. Bhabha explains mimicry as an overstated repetition that doesn't quite repeat but forces slippage; while the doppelgänger replaces the primary image, mimicry stresses and re-emphasizes it in order to have an impact on reflection.

Marthurine is an example of a figure that is capable of undermining hierarchies. She exploited her role as a jester to hold up a mirror to the king, because she was allowed to within this role. A jester, in an absolutist court, was the only person permitted to convey newly gained information and damaging news truthfully. She observed the atmosphere of the city and would gather word from public voices overheard while riding on her horse through Paris. When telling her jokes to the king, she often presented herself as a soldier in self-made regimental dress. In her spoof as a soldier, she was able to raise her voice on behalf of the citizens of Paris. In wearing the costume, she uses a sort of fool's cap as an implement of invulnerability and invisibility. The fool's cap symbolizes her independent agency by mocking the king and his politics, the inhabitants of Paris, as well as herself. With this form of mimicry, the narration of Marthurine discloses the ambivalence of the predominant idea of normalcy, when she is performing a position 'that is unmarked by the discourse' (Bhabha 2004a, p. 114).

Marthurine's paper is called Les Caquets de l'Acouchée - meaning cackling - and is a synonym for gossip (cf. Lemaignan 2009). Yellow press journalism uses fake interviews, misleading headlines, pseudoscience, and a parade of false learning from presumed experts; here this kind of journalism plays an essential role in degrading the power of the monarchy by using the technique of mimicry to carry Marthurine's insights into the court. ${ }^{4}$ The paper suggests the idea that gossip could contribute to an emerging public sphere of political debate. Through her supply of an independent publication, Marthurine shaped a movement of empowerment, with the chance to speak with one own voice. Gossip plays an important role here: 'Les Caquets' is an illustration of how the slippery, sloppy 
talkativeness of gossip might have operated as public critique, despite the attempts to silence it.

Homi Bhabha explains mimicry practices - such as the humorous and overstated reiterations of stigmatizing arguments, comments or situations - as routines that reflect the demand for identity - its slippage, its excess, its difference (Bhabha 2004a, p. 122) as a dual approach: 'As colonialism produces mimicry itself, mimicry "emerges as one of the most elusive and effective strategies of colonial power and knowledge" (Bhabha 2004a, p. 121). Here, Bhabha illustrates the powerful nature of colonial mimicry, but leaves it there; there is ambiguity as to whom it gives power; consequently there is the suggestion that the colonized can use it to subvert the colonizer. Bhabha argues that colonial mimicry is 'the desire for a reformed, recognizable other, as a subject of a difference that is almost the same, but not quite' (Bhabha 2004a, p. 122). In that sense, the other becomes almost the same as the colonizer, but never quite fits in with the hegemonic cultural and political systems that govern both of them. The actions of mimicry reveals concurrent fascination and disgust, which is the experience of a decentralized figure of ambivalence. The process of mimicry represents the Janus-faced idea of colonialism and 'othering', with its desired and simultaneously stigmatized otherness of race, sex and gender. Bhabha continues to show that for (colonial) mimicry to work, it must continue to express its difference, which he terms ambivalence.

While Bhabha is speaking of an imperceptible strategy, mimicry opens a field for action and agency as a result of discourse as conscious resistance. Ultimately, because mimicry requires this 'slippage' to function, it gives power not only to the colonizer, but also becomes the subversive tool of the colonized. Albeit Bhabha intends mimicry as a subliminally utilized strategy, it seems to be an important addition to the toolbox of resisting commonplace racism, sexism and homophobia. The figure of the jester, embodied by Marthurine, exhibits the ambivalence of mimicry since she employs the double face of the situation.

The diverse mimicry practices that Marthurine uses can be seen as a probing of rules, habitus and status social systems of order when political commentary is insubstantial. Foolish ways of mimicry, such as Marthurine's cross-dressing, may produce arbitrary laughter, focusing on light relief. Additionally, Marthurine exploits the opportunity of dealing with conflict without using involved theoretical arguments or setting the scene for tragedy. Jokes, as Freud argues (1992 [1915]), are constructing a level for a playful game, allowing insights into conflict through emphasizing and 
taking resistance by surprise. Mimicry practices function as joyful doubles of reality. Legally, socially and culturally the community is exclusively regulated by citizenship regulations; hereby mimicry enables playful use of the rules and regulations for reinterpretation. The appeal lies in the disruption of the political framework, in trying to create new scenarios through repetition - a chance to revisit. Generally, practices of mimicry refer to social and political regimes, they are markers of the democratic processes. Through these practices, affiliation and exclusion become a visual and effective means to recover agency of formerly uncontrollable dictates. While Stuart Hall emphasizes that the very parts of institutional habits that cannot be destroyed are to be found in, '[...] informal and unsaid ways through daily practices' (Hall and du Gay 1996, p. 32). By detaching oneself from acquired cultural conventions and schemes, mimicry gains agency through taking a hybrid position. Bhabha's concept traces the production of a domain that doesn't utilize the theoretical arguments of the discourse around race and discrimination. Through humour, a distorting mirror reflects the colonist's desire for a reformed, recognizable 'other' as a subject of difference. The colonialist sees mimicry as double vision in which the disclosure of ambivalence toward colonial discourse also disrupts its authority.

\section{CARNIVAL AL LAJIIN_AL-LAJIÀAT: CONTEMPORARY Practices of Mimicry}

In political, legal and humanitarian discourse, individual and practical activities - undertaken to gain agency - often remain unseen or even invisible. While still questioning what are the ways to gain agency in situations leading to stigma, how does one deal with labelling? Or, to ask this another way around: how can one relabel the stigmatized? On 20 March 2016, a group of so-called refugees, in collaboration with the campaign 'My Right is your Right' and several cultural institutions, organized the Carnival Al-Lajiin_Al-Lajiàat (Arabic for 'female refugee/male refugee') in Berlin-Kreuzberg - one of the most famous and discussed Berlin quarters, proclaimed for the past 30 years as a multi-cultural district. ${ }^{5}$ Here, carnival symbolizes the element of mimicry that reveals diversity, beyond the dominant discourse. Samee Ulaah, one of the organizers of 'My Right is your Right', told me that the Carnival Al-Lajiin_Al-Lajiàat is inspired by 
Michail Bakhtin's theory of carnival (cf. Bakhtin 1984). Carnival is a popular ancient heritage ritual where art and life meet within a collectively performed play, allowing moments of exaggeration and the grotesque. According to Russian philosopher Bakhtin, in blurring the borders between actors and spectators, carnival reveals a rich variety of voices that join to deny convention, disobey hierarchies and stimulate genuine human exchange - a currency leading to agency, that additionally is polyphonic. The carnival has many forms of expression (Fig. 1).

Happening on a grey weekend, in the middle of the 'alternative' kiez of Berlin-Kreuzberg, the procession of the Carnival Al-Lajiin_Al-Lajiàat seemed to be a combination of carnival and demonstration; a caravan of decorated vehicles and people wearing costumes, referring to their very different backgrounds and ideas of carnival. New images and costumes were introduced to the established guise of the fool within the western carnival. In welcoming all, the carnival offered many international ideas of the grotesque forms of mimicry. The initiative came from a small collective of refugees from their base in the studio of the Maxim Gorki theatre of Berlin. Backed up by a collective of city theatres (Stadttheater), such as the Berliner Ensemble and Schaubühne, as well as Deutsches Theater, the Carnival Al-Lajiin_Al-Lajiàat became a spectacle of impressive diversity.

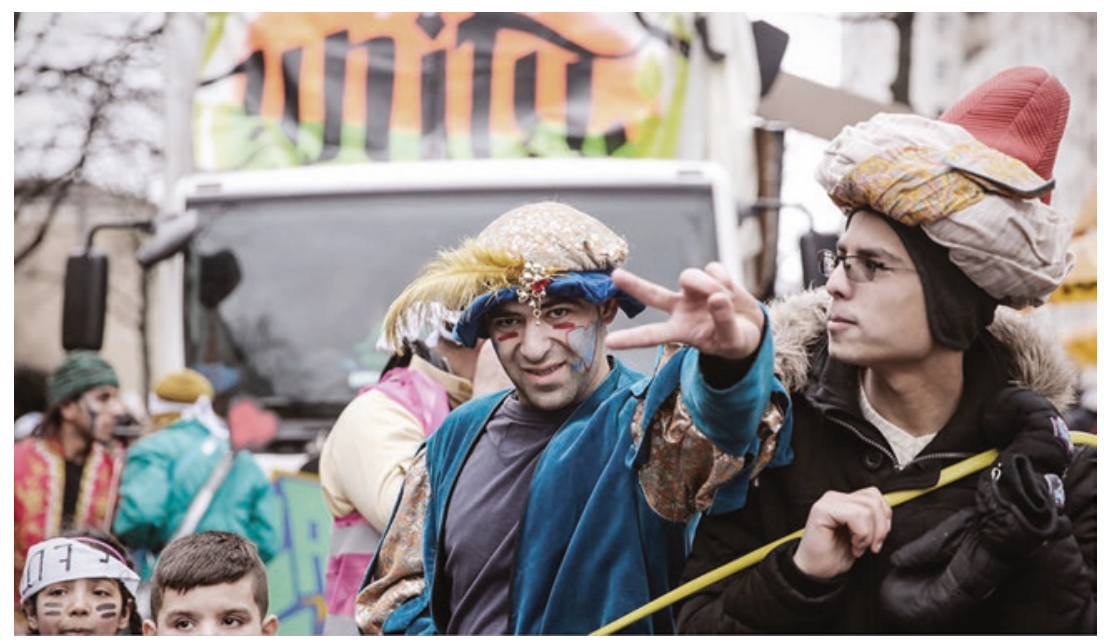

Fig. I Carnival Al-Lajiin_Al-Lajiàat in Berlin-Kreuzberg. (Photo: Thari Jungen) 
By focussing on the idea of the laughter of solidarity amongst the camouflaged, no logos of any political or cultural institution were shown. In addition to the support of the theatres - loaning their costumes and stage equipment - countless citizens, urban activists, and organizations of refugees became involved. The idea of carnival, with the original meaning as 'celebration of the flesh', was performed through the streets with the participation of more than 5000 people. $^{6}$

When one of the costumed participants wanted to start the countdown to a small performance in the back of a truck, he asked: 'Should we count in the German language?' The gathered jovial group he was addressing answered the question firmly with: 'No!' Instead, somebody proclaimed loud and clear: 'Everybody should learn to count in Arabic!' - which was then put into effect immediately after. By raising the voice within a spontaneous assembly of strangers, the very idea of assimilation and participation through language produced an unexpected response to the contrary, thereby gaining agency by incidental comment on the political situation. As Mikhail Bakhtin (1984) determines: 'Carnival contains a laughter from below, directed to the privileged and the ruling order' (Fig. 2).

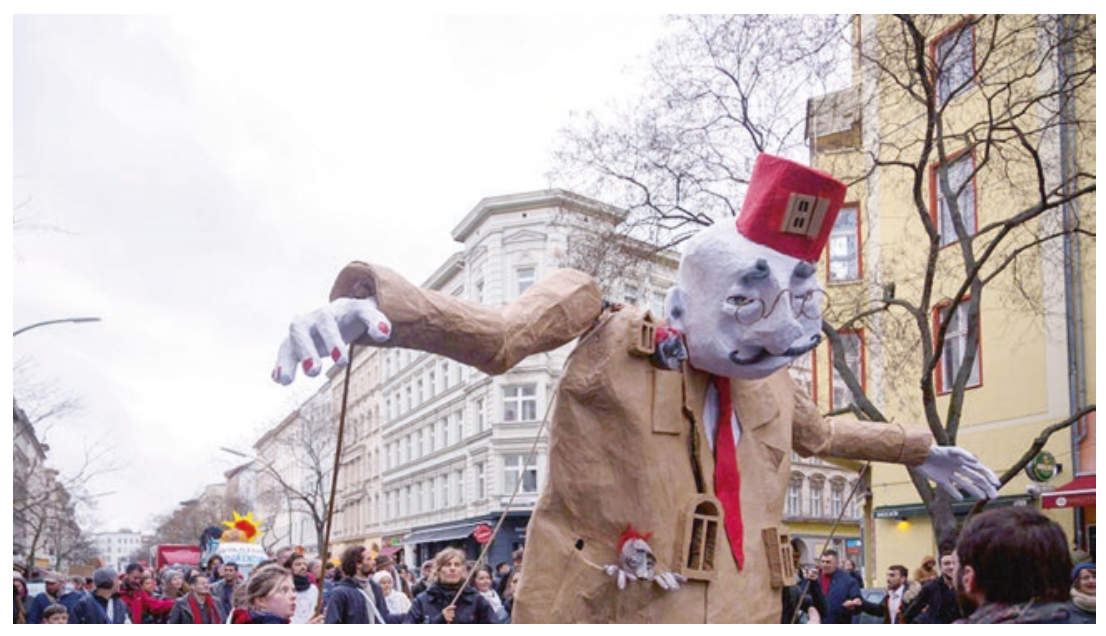

Fig. 2 Many participants of the Carnival Al-Lajiin_Al-Lajiàat manifested their solidarity and sympathy for so-called refugees through display of puppets and costumes. (Photo: Thari Jungen) 
In a similar way to Marthurine, the so-called refugees not only brought about the carnival, they also published a newspaper: Daily Resistance. ${ }^{8}$ Projects such as this are establishing public spaces of critique and selfempowerment by using mimicry and parody as one way of speaking out. Both of these projects - the newspaper Daily Resistance and the group 'My Right is your Right' - were inaugurated by people who have fled; they are dedicated to people in the refugee camps and made by people from the refugee camps. In both instances, they mock their own situation to break the isolation. They return from the imposed status of a supposed Mängelwesen (being a person without rights or agency) to being individuals with diverse wishes, needs and realities. ${ }^{9}$

In looking at the practice of labelling let us give insight into how attributions by others are formed, dependent on and regulated through habitus, politics and legal rights.

Stereotyping is not the setting up of a false image which becomes the scapegoat of discriminatory practices. It is a much more ambivalent text of projection and introjection, metaphoric and metonymic strategies, displacement, over-determination, guilt, aggressivity; the masking and splitting of 'official' and phantasmatic knowledges to construct the positionalities and oppositionalities of racist discourse. ${ }^{10}$ (Bhabha 2004b, p. 117)

Mimicry, as an approach of ethnology, reveals the dubiety of concepts such as identity and similarity; moreover the notion of mimicry discloses the most important categories of imitation as in 'belief and desire' (de Tarde 1979 [1890], p. 217), as shown in the very different practices within the regime of normalcy. Since mimicry can become an act of resistance, through joking, mocking, 'vogueing' or specific rites, it reveals the ambivalence of the homogenous desire for normalcy, assimilation and power within modern nation states. Mimicry practices using gaps within bureaucratic, social and political regulations to re-examine the practice of relabelling and subjectivation in daily life.

When the German 'Welcome Culture' (Willkommenskultur) emerged in 2017, Simone Dede Ayivi - a female black activist - wrote an article in the German newspaper Die Zeit, wherein she was referring to a black volunteer in one of the refugee camps who had been interrupted in her work when another helper said: 'Du musst nicht helfen. Wir helfen!' ('You must not help. We help!', author's translation). ${ }^{11}$ It is no surprise when even voluntary workers of the supposed 'Welcome Culture' themselves are not 
immune to labelling and stereotyping as racist practices. This example, however, shows how diverse constructions of labelling have become acceptable to us, as well as showing the ambivalence involved in the application of such labels. The practice of labelling has become ingrained within every day identification. Labelling involves the selection of particular characteristics by the labeller; these are exaggerated and simplified and so selfidentity and behaviour may be determined or influenced by the terms used to describe or classify.

Those labels or fantasies of selected characteristics, that are gaining the effect of a 'natural' inscription, are unchangeable according to Homi Bhabha. 'Like fantasies of the origins of sexuality, the productions of "colonial desire" mark the discourse as "a favoured spot for the most primitive defensive reactions such as turning against oneself, into an opposite, projection, negation."' (Bhabha 2004b, p. 116) Racism, as Mark Terkessidis (1997, pp. 172-87) points out (and here sexism may be added in as well), is not a prejudice but rather very much of a part of the assembly of social values, as well as part of collective knowledge. "Labelling is referring to the modern nation state's heightened demand for normalcy" as I would equate with the predominant discourse (Goffman 1986 [1963], p. 7). Erwing Goffman states that today's stigmas are the result not so much of ancient or religious prohibitions, but of a new demand for normalcy. This demand does not only affect the colour of the skin, but specific cultural and social codes. Living in a divided world, according to Goffman, there are the forbidden places where the revelation of otherness means vulnerability and risk, where people of colour are sorely tolerated, and other places where people of colour are more easily accepted without need to dissimulate, to camouflage and hide in order to protect themselves (Goffman 1986 [1963], p. 13). 'What are unthinking routines for normals can become management problems for the discreditable' (Goffmann 1986 [1963], p. 88). Here, Goffman points out, the ambivalence and the plurality of the roles and patterns that exist and can change according to the very different situations. Within labelling, seen as an act of signification, lies a device that reduces, normalizes and fixes the difference of subjects and communities with their imposed identity. The conscious repetition of such practice belies a vital, very physical sense of discomfort, thus prompting the mind to reflect on the reasons behind the need to adhere to the use of labels. Performances - such as playing with language, highlighting, manifesting shifts and transformations - are usual forms of subversive (language) politics against the hegemonic and homogenous influence of western cultures. 
The performance collective Kanak Attack engages in a wide range of subversive language politics; by electing to use an ethnolect known as 'kanakisch' they offer their own new interpretation of the abusive and racist origin of the term Kanake. ${ }^{12}$ Their ethnolect uses a typically Turkish accent, full with exaggeration, providing a jokey response to the ubiquitous stereotypical labelling of the Turkish. Thus 'kanakisch' became a popular form of slang, even throughout the non-Turkish community in Germany. Mimicry creates the possibility to explore symbolic situations through provocative performance, in the copying and representation of social situations, personal individual characters or role models. ${ }^{13}$

Although stigmatized and labelled subjects do not actually represent a passive, homogenous collective at all, rather they are persons with agency, diverse wishes and competencies. In asserting their legal rights, they engage in different creative forms to achieve a better daily life within their differing statuses of citizenship. Conversely, this does not imply the ignoring of particular histories, trauma or fears. Additionally, it does not prompt an agreement based solely on the terms of the current legal or political situation.

In contrast to the external valuation made by Goffman of the labelling concept, Michel Foucault describes the idea of subjectivation, within technology of the self as a mental attitude. He conceives of the subject as a being, existing and therefore a quasi- complete subject, logically described as a 'final production'. Foucault suggests to negotiate the procedures of subjectivation as an object of analysis instead of defining the category of the subject itself. The central thesis of Foucault (1980) points out that what is done, the subject itself, defines the very moment of creating history - or saying it the other way around, erroneously we imagine practice defines itself out of creating and forming. ${ }^{14}$ Through examining the historification of subjectivation, Foucault breaks with the notion of sovereign and constitutive subjects, while perceiving subjectivation according to becoming subject, and therefore gains the ability to decentralize the subject.

Mimicry sheds light on the variety of instruments, objects and methods, as practical methodological tools of analysis that makes labelling practices more visible. Imitation and mimicry are considered forms of performance itself that highlight differentiation in the modes of production of representation, politics and identity. The political dimension of imitation seems always to refer to a presumed society of origin, and by doing so it constructs an exclusive fictional community (Bielefeld 1997, 
p. 99). The inevitable alliance of the origin and the mimicry itself seems to be concurrent with the predominant idea of the society of origin, moreover appropriated by imitation and, at the same time, re-emphasizing its antagonistic qualities; the falsification, the false, if not to say the fraudulent. These negative external ascriptions are common daily acts of stigmatization. The gap - between the process of identification and the person subjected to this process - enables one to emancipate and reflect on the truth through the means, or strategy, of mimicry.

By saying that this process of imitation is never complete, Bhabha argues that there is always something lacking. There are always cultural, historical, and racial differences which hinder one's complete transformation into a subject that is not subjectivated and not labelled from the outside. According to Nikita Dhawan and Maria do Castro Varela (2015, p. 221), I would formulate that the agency of the colonized lies in shifting the meaning. Every attempt at stereotype - with whom the colonized, stigmatized or labelled 'other' is determined as fixed to a definitive picture - is nevertheless inevitably fragmented in itself and self-contradictory. Here, Bhabha shaped the term hybridity that describes the cultural and psycho-social effects of colonialism, and also points to the inherent ambivalence of the discourse (meaning every discourse) within. By doing so, he attains a level of visibility, revealing the ambivalence of the dualism of orient and occident, as well as of colonizer and colonized, or the exclusive and inclusive (cf. Young 2004, p. 26).

\section{CONCLUSION}

Jokes, spoofs and parodies aim to reflect the sphere of emancipation and empathy through reiteration. In trying to reclaim the question of equality - through the creation of alternative views of daily life, and a utilization of the subject's vulnerability to linguistic and parodic mimicry - there emerges a discourse on debasement and reflection. Irony questions our ability to define ourselves in reference and deference to others. The theory and its practice reflects and retransfers - it sets up a 'live' perpetuating capacity for rethinking - whereas discourse, increasingly routinely criticized for its limitations, becomes an end in itself, existing purely to serve the needs of western academic discourse rather than seeing theory as a tool of intervention, or seeing theory as supplementary to practice. ${ }^{15}$ Moreover, by actively highlighting the contradictions and objections of society though personal appropriation and exploiting the potential of 
humour to reach others, practices of mimicry can become acts of resistance. Furthermore, such performed technologies of the self, demonstrate the ambivalence of the homogenous desire for normalcy, assimilation and power in modern nation states. ${ }^{16}$ Diverse subjectivation and labelling practices in everyday situations are calling for the intervention of jokes and humour, although mimicry practices are only minor supportive acts of self-empowerment that do not in themselves replace - or necessarily change - any legal or political situation. They refer to the ambivalent discourse of appropriation and assimilation as both practices and theory of mimicry. The carnival, in particular, perfectly expresses the idea that citizenship is more than a legal right; citizenship also consists of a demand for social, political and cultural agency.

\section{Notes}

1. Erwing Goffman's theory on stigma deals with techniques of the self, by analysing the specific interactive practices of individualities with their pictures from outside, answering to the institutionalized scripts with regard to their respective external perception. While Michel Foucault's notion of the 'technologies of the self' references regulation and governmental practices within the perspective of flexible, normalized spaces for different possibilities of lifestyle attended to the individualities. Cf. Michel Foucault (1988) Technologies of the Self. Also, Goffman, Erving (1986) Stigma: Notes on the Management of Spoiled Identity.

2. Cf. Edouard Fournier: 'Feu de Joye de Mme Marthurine', in Variétés historiques et littéraires, (Paris, Jannet), 1855-1863, p. 274. See also: La cholère de Mathurine, contre les difformez reformateurs de la France, $\grave{A}$ sa grande Ame, (Paris), pp. 168-73.

3. Here, the term performance is used as an ephemeral concept - not necessarily attached to definitive categories as, for example, within the arts - but inside the alliance of acting as a conscious statement, practice or movement, referring to Michel Foucault's term of self-technology (Foucault 1988).

4. The term 'yellow press' or 'yellow journalism' appeared first in Ervin Wardman's New York Press in late January 1897, as a concise expression for 'new journalism'. Over the years, the term is used to describe misconduct in news-gathering. 'The term has served as a derisive shorthand for denouncing journalists and their misdeeds, real and imagined' (cf. Campbell 2001).

5. For more information about the collaborative project please see, www. myrightisyourright.de, date accessed 18 February 2018. 
6. The meaning of the original Italian term 'carnevale' refers to carnem (meat) and levare (remove). The etymology embedded in its meaning is as a dared festival where the flesh of bodies is removed by costumes. Translated as 'flesh farewell' in the figurative sense, the term also marks the festivity as a Christian tradition when Lent begins, forty days before Easter.

7. Since the Bolshevik committee eventually took responsibility to release (belatedly) Bakhtin's famous study Rabelais and his World (1984), the question relating humour to government, power and discipline was first allowed to be asked publicly only after 30 years had passed by. The potential benefits of parody, spoofs and jokes as daily - not necessarily - political acts, is expressed within the dissertation of Mikhail Bakhtin, writing from a subversive classification. For further reading please see, Robin Andrews (2011) 'Bakhtin: Carnival against Capital, Carnival against Power' in Ceasefire, 09/2011, www.ceasefiremagazine.co.uk/in-theory-bakhtin-2, date accessed 26 January 2017.

8. www.dailyresistance.oplatz.net, date accessed 18 February 2018.

9. Arnold Gehlen points out that to rule the world a man, apart from the owned deficiencies (Mängel), must not only be able to take action, he has also to be capable of development. Gehlen emphasizes that the degree to which a human being is defenceless is commensurate with its surroundings, thereby he proposes to strengthen both institutions and organizations in both the state and private sectors (for further reading please see, Gehlen 2016 [1940]).

10. Comparing both terms - labelling as well as stereotyping - the practice of stereotyping forces, in Homi Bhabha's words, the codifying of whole communities while the discourse of labelling seeks to normalize individuals (for further reading please see, Bhabha 2004b, p. 117).

11. Simone Dede Ayivi describes in her article, entitled as 'Wir müssen über Rassismus reden' ('We need to talk about racism', author's translation) her perspective as a black German citizen due to the period of the so-called 'summer of migration'. cf. www.zeit.de/kultur/2015-10/integrationrassismus-fluechtlingshilfe-10nach8, date accessed 18 February 2018.

12. Kanak Attak is a community of different people from diverse backgrounds who share a commitment to eradicate racism from German society; amongst others they are known for their ethnolect 'getürkt'. Their manifesto states: 'We sample, change and adapt different political and cultural drifts that all operate from oppositional positions' [author's translation], cf. www.kanakattak.de, date accessed 18 February 2018.

13. Oliver Marchart $(2007$, p. 80$)$ points to the fact that Bhabha's theory of subversion, like every other theory of subversion, has a problem in proving its threat toward power - because it isn't revolution or open protest. He relegates to the fact that power structures themselves need a certain 
amount of subversion in order to exert power, as well as preserve their stability, while also remarking a difference to other forms of protest. Contained within the subversion of mimicry, there aren't any defined claims and goals, thus cannot be proven or quantified, only be theoretically formulated.

14. For further reading and a more expansive overview of this discourse, the following is recommended: Paul Veyne (1997) 'Foucault Revolutionizes History' in Davidson, Arnold I. (ed.) Foucault and His Interlocutors, pp. 146-82.

15. Focussing on the gap between theory and practice: Elleke Boehmer (2013) 'Revisiting Resistance' in The Oxford Handbook of the Postcolonial Studies, pp. 307-21.

16. By referring to the concept of citizenship, as Seyla Benhahib (2008, p. 35) states, ' $[\ldots]$ we face a paradox internal to democracies, namely, that democracies cannot choose the boundaries of their own membership democratically'. Although this state-centred perspective may be criticized, through the agreement that citizenship must also be defined as a social process through which individuals and social groups engage in claiming, expanding and losing rights (Isin and Turner 2002, p. 4). Since Engin Isin, amongst other theorists, speaks of the practice of 'acts of citizenship', they describe those moments and habits through which subjects actively produce citizens by governing themselves (Isin 2009, p. 367).

\section{REFERENCES}

Anonymous. 1616. La cholère de Mathurine, contre les difformez reformateurs de la France, à sa grande Amye. Bordeaux: Jean Milot.

Bakhtin, M. 1984. Rabelais and His World. Bloomington: Indiana University Press.

Benhahib, S. 2008. Another Cosmopolitanism. New York: Oxford University Press. Bhabha, H.K. 2004a. On Mimicry and Men: The Ambivalence of Colonial Discourse. In The Location of Culture. London: Routledge.

. 2004b. The Location of Culture. London/New York: Routledge.

Bielefeld, U. 1997. Das Eigene und das Fremde. Nener Rassismus in der Alten Welt? Hamburg: Junius Verlag.

Boehmer, E. 2013. Revisiting Resistance. In The Oxford Handbook of Postcolonial Studies, ed. G. Huggan. Oxford: Oxford University Press.

Campbell, W.J. 2001. Yellow Journalism: Puncturing the Myths, Defining the Legacies. Westport: Greenwood Publishing Group.

Castro Varela, M. do M., and N. Dhawan. 2015. Postkoloniale Theorie: Eine kritische Einführung. Bielefeld: Transcript.

de Tarde, G. 1979. Les lois de l'imitation: etude sociologique. Paris: F. Alcan. 
Didi-Huberman, G. 2001. Das Paradox der Phasmiden. In Phasmes. Cologne: DuMont.

Foucault, M. 1980. Power/Knowledge: Selected Interviews and Other Writings, 1972-1977. New York: Vintage.

- 1988. Technologies of the Self: A Seminar with Michel Foucault. Amherst: The University of Massachusetts Press.

Fournier, E. 1855a. Feu de Joye de Mme Mathurine (An Advertisement Placed) in Variétés Historiques et Littéraires. Paris: Jannet.

- (ed.) 1855b. Les Caquets de l'Accouchée. In Les Essais de Mathurine, Paris: Jannet.

Freud, S. 1992. Jokes and Their Relation to the Unconscious. Trans. Joyce Crick. Harmondsworth/New York: Penguin.

- 2003. The Uncanny. Trans. David McLintock. Harmondsworth/New York: Penguin.

Gehlen, A. 2016. Der Mensch: Seine Natur und seine Stellung in der Welt. Frankfurt am Main: Vittorio Klostermann.

Goffman, E. 1986. Stigma: Notes on the Management of Spoiled. New York: Touchstone.

Hall, S., and P. du Gay. 1996. Questions of Cultural Identity. London: Sage UK.

Isin, E.F. 2009. Citizenship in Flux: The Figure of the Activist Citizen. In Subjectivity, 29/S1. Basingstoke/New York: Palgrave Macmillan.

Isin, F.E., and S.B. Turner. 2002. An Introduction. In Handbook of Citizenship Studies, ed. E.F. Isin et al. London: Sage UK.

Lemaignan, M. 2009. Mathurine ou la question d'un tiers espace de l'hétérodoxie, dans La Confession catholique du Sieur de Sancy d'Agrippa d'Aubigné' in L'Atelier du Centre de Recherches Historiques. http://journals.openedition. org/acrh/1234\#quotation. Accessed 10 Mar 2018.

Marchart, O. 2007. Der koloniale Signifikant. Kulturelle 'Hybridität'und das Politische, oder: Homi Bhabha wiedergelesen. In Kultureller Umbau, Räume, Identitüten und Re/Präsentationen, ed. M. Krönke et al. Bielefeld: Transcript.

Terkessidis, M. 1997. Woven into the Texture of Things. Rassismus als praktische Einheit von Wissen und Institution. In Evidenzen Im Fluß: Demokratieverluste in Deutschland; Modell D - Geschlechte - Rassismus - PC, ed. A. Disselnkötter. DISS: Duisburg.

Veyne, P. 1997. Foucault Revolutionizes History. In Foucault and His Interlocutors, ed. Arnold I. Davidson. Chicago: University of Chicago Press.

Young, R.J.C. 2004. White Mythologies. Writing History and the West. London/ New York: Routledge. 
Open Access This chapter is licensed under the terms of the Creative Commons Attribution 4.0 International License (http://creativecommons.org/licenses/ by $/ 4.0 /$ ), which permits use, sharing, adaptation, distribution and reproduction in any medium or format, as long as you give appropriate credit to the original author(s) and the source, provide a link to the Creative Commons licence and indicate if changes were made.

The images or other third party material in this chapter are included in the chapter's Creative Commons licence, unless indicated otherwise in a credit line to the material. If material is not included in the chapter's Creative Commons licence and your intended use is not permitted by statutory regulation or exceeds the permitted use, you will need to obtain permission directly from the copyright holder.

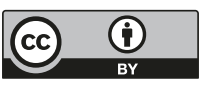

